\title{
Methodological Study on Voluntary Greenhouse Gases Reduction for Shore Power System
}

\author{
Leilei Liu' ${ }^{1}, X u$ Guo ${ }^{1}$, Jian Ding ${ }^{2}$, Hongliang Wang ${ }^{3}$ \\ ${ }^{1}$ Tianjin Research Institute for Water Transport Engineering, Key Laboratory of Environmental Protection Technology on Water \\ Transport, Ministry of Transport, Tianjin, China \\ ${ }^{2}$ Tangshan Port Group Co., LTD \\ ${ }^{3}$ Tianjin Five Continents International Container Terminal Co., LTD
}

\begin{abstract}
Voluntary emission reduction of greenhouse gases is conducive to reducing carbon dioxide $\left(\mathrm{CO}_{2}\right)$ emissions and fostering a carbon trading market. Voluntary greenhouse gas emission reduction methodologies can be used to determine project baselines, demonstrate additionality, calculate emission reductions, and develop monitoring plans. Marine fossil fuel combustion is an important source of greenhouse gas emissions in port. Through the implementation of marine shore power system, it is possible to replace fuel consumption with electricity and significantly reduce greenhouse gas emissions during berthing. Through the analysis and study on shore power system, the methodology of voluntary greenhouse gas emission reduction for shore power system is formed, which is conducive to promoting the participation in carbon emissions trading and promoting the promotion and use of shore power system.
\end{abstract}

Greenhouse gas emissions in ports mainly come from the production of loading and unloading and the burning of fossil fuels during the berthing period of ships. The implementation of shore power system can effectively control greenhouse gas emissions in port areas. Such projects have the characteristics of large scale, significant energy saving and emission reduction benefits. It is suitable for carrying out voluntary emission reduction trading as a typical project of transportation industry. At present, China has basically built a voluntary greenhouse gas emission reduction trading and its supporting system. The National Development and Reform Commission promulgated the Interim Measures for the Management of Voluntary Greenhouse Gas Emission Reduction Transactions [1] and the Guidelines for the Verification and Certification of Voluntary Greenhouse Gas Emission Reduction Projects[2]. In the field of transportation, some methodologies have been published, such as "Reducing Emissions through Electric and Hybrid Electric Vehicles (Methodology No. CMS-048-V01)" [3]. However, there is a lack of emission reduction certification methods for shore power system at present. In this paper, according to the requirements of voluntary greenhouse gas emission reduction trading, the methodology of voluntary greenhouse gas emission reduction is proposed for shore power system.

\section{Methodological study}

\subsection{Definition and scope of application}

(1)Relevant definition

Shore power system: it means that during the period of berthing, the generator on the ship will be stopped and the power supply on land will be used instead.

Unit time fuel consumption: Fuel consumption per unit time of power generation by ship auxiliaries during berthing.

Unit time power consumption: Electricity consumed per unit time by shore power system during berthing.

(2) Explanation of scope of application

This methodology is applicable to the calculation of emission reduction caused by the use of shore power instead of fuel during berthing of ships.

This methodology is limited to projects with annual emission reductions of less than 60,000 tons of carbon dioxide.

The principle of selecting all kinds of parameters is to select the measured data first.

\subsection{Base line}

In determining the baseline scenario, the baseline ship and the project ship (ships using shore power system during berthing) should provide comparable services. It is required that the power difference of fuel engine (including main engine and auxiliary engine) should be within $\pm 20 \%$ respectively. 


\subsection{Project boundary}

Project boundaries include:

(a) Ships using shore power system during berthing.

(b) Geographical boundaries of ports where ships berthing.

(c) Ancillary facilities such as shore power supply equipment and power sources (e.g. power grids).

\subsection{Additional Demonstration}

Mode 1:

Demonstrate that project activities can't be implemented because of one or more obstacles, such as the obstacles faced by the construction of shore power system, the policy and regulation obstacles faced by power supply services (e.g. unclear price of power supply, policy-based market barriers), and mandatory laws and regulations.

\section{Mode 2:}

Prove that the proportion of shore power in the project area is less than $20 \%$ before the implementation of the project.

\subsection{Baseline calculation}

The determination of the baseline is based on the unit time fuel consumption of engine power generation. It is obtained by multiplying the berthing time and the number of ships, the emission coefficient of the fuel used.

The calculation formula is as follows.

$$
B E_{y}=\sum f_{i, y} \times E C_{P J, i, y} \times N C V_{f_{\text {ful } l, i, y}} \times E F_{\mathrm{CO}_{2}, i, y} \times I R^{t}
$$

Among them:

$$
B E_{y} \text { :Baseline emission in } \mathrm{Y} \text { year }\left(\mathrm{t} \mathrm{CO}_{2}\right) \text {. }
$$

$E C_{P J, i, y}$ :Electricity supplied by shore power system for type I ships in Y year(MWh).

$N C V_{\text {fuel }, i, y}$ : Net calorific value of fossil fuel consumed by type I $\operatorname{ships}(\mathrm{GJ} / \mathrm{t})$.

$E F_{\mathrm{CO}_{2}, i, y}$ :Carbon dioxide emission factors of fossil fuel consumed by type I baseline ships $\left(\mathrm{t} \mathrm{CO}_{2} / \mathrm{GJ}\right)$.

$I R^{t}$ : Technical improvement factor of t-year baseline ship. The default value is 0.99 .

$t$ : Year $t$ after the commencement of project activities.

$f_{i, y}$ : Energy consumption ratio ( $\mathrm{t} / \mathrm{MWh}$ ) of datum line ships and project ships with type I in $\mathrm{Y}$ year(t/MWh).

$$
f_{i, y}=\frac{S F C_{\text {fuel }, i, y}}{S F C_{\text {elec }, i, y}}
$$

Among them:

$S F C_{f u e l, i, y}$ : Fuel consumption per unit berth time of baseline ships with type I in Y year $(\mathrm{t} / \mathrm{h})$.

$S F C_{\text {elec }, i, y}$ : Electricity consumption per unit berth time of project ships with type I in Y year(MWh/h).

\subsection{Project Emissions}

Project emissions refer to the carbon dioxide emissions indirectly generated by ship power consumption.

The calculation formula is as follows.

$$
P E_{y}=\sum_{i} E F_{\text {elec } i, y} \times E C_{P J, i, y} \times\left(1+T D L_{i, y}\right)
$$

Among them:

$P E_{y}$ : Total project emissions in year $\mathrm{Y}\left(\mathrm{t} \mathrm{CO}_{2}\right)$.

$E F_{\text {elec,i,y }}$ : Carbon dioxide emission factors of fossil fuel consumed by type I project ships $\left(\mathrm{t} \mathrm{CO}_{2} / \mathrm{GJ}\right)$.

$E C_{P J, i, y}$ : Power supply for type I project ships in year $\mathrm{Y}(\mathrm{MWh})$.

$T D L_{i, y}$ :Power loss in transmission process $(\%)$.

\subsection{Leakage}

This methodology does not require calculation of leakage.

\subsection{Emission reduction}

Emission reductions are calculated as follows.

$$
E R_{y}=B E_{y}-P E_{y}-L E_{y}
$$

Among them:

$E R_{y}$ : Emission reduction in year $\mathrm{Y}\left(\mathrm{tCO}_{2}\right)$.

$B E_{y}$, Baseline emission in year $\mathrm{Y}\left(\mathrm{tCO}_{2}\right)$.

$P E_{y}$ : Project emission in year $\mathrm{Y}\left(\mathrm{tCO}_{2}\right)$.

$L E_{y}$ : Leakage in year $\mathrm{Y}\left(\mathrm{tCO}_{2}\right)$.

\begin{tabular}{|c|c|c|}
\hline Indicator & Description & Monitoring method \\
\hline$T D L_{i, y}$ & $\begin{array}{l}\text { Power loss in transmission } \\
\text { process }(\%)\end{array}$ & $\begin{array}{l}\text { Using data published by state authorities. } \\
\text { Or adopting the default values of "Baseline, Projects and/or Leakage } \\
\text { Emission Calculating Tool Caused by Power Consumption ". }\end{array}$ \\
\hline$S F C_{\text {fuel }, i, y}$ & $\begin{array}{l}\text { Fuel consumption per unit } \\
\text { berth time of baseline ships } \\
\text { with type I in } \mathrm{Y} \text { year }(\mathrm{t} / \mathrm{h}) \text {. }\end{array}$ & \multirow{2}{*}{$\begin{array}{l}\text { The data can be obtained in the following order: } \\
\text { (a) Data published by state authorities. } \\
\text { B) Manufacturer design data. } \\
\text { C) Academic research data. } \\
\text { D) IPCC or other international defaults. } \\
\text { E) Sampling based on the latest version of the applicable Guidelines for the } \\
\text { Use and Investigation of Project Activities and Planning Activities. }\end{array}$} \\
\hline$S F C_{\text {elec }, i, y}$ & $\begin{array}{l}\text { Electricity consumption per } \\
\text { unit berth time of project } \\
\text { ships with type I in Y } \\
\text { year(MWh/h). }\end{array}$ & \\
\hline$N C V_{\text {fuel }, i, y}$ & Net calorific value of fossil fuel & National literature data or IPCC defaults \\
\hline
\end{tabular}

\subsection{Monitoring indicators and methods}

The monitoring indicators and methods for the project are shown in Table 1.

Table 1. Monitoring indicators and methods 


\begin{tabular}{|c|c|c|}
\hline Indicator & Description & Monitoring method \\
\hline & consumed by type I ships $(\mathrm{GJ} / \mathrm{t})$. & \\
\hline$E F_{\mathrm{CO}_{2}, i, y}$ & $\begin{array}{l}\text { Carbon dioxide emission } \\
\text { factors of fossil fuel consumed } \\
\text { by type I baseline ships }(\mathrm{t} \\
\left.\mathrm{CO}_{2} / \mathrm{GJ}\right) \text {. }\end{array}$ & National literature data or IPCC defaults \\
\hline$E F_{\text {elec }, i, y}$ & $\begin{array}{l}\text { Carbon dioxide emission } \\
\text { factors of fossil fuel consumed } \\
\text { by type I project ships }(\mathrm{t} \\
\left.\mathrm{CO}_{2} / \mathrm{GJ}\right) .\end{array}$ & $\begin{array}{l}\text { The data can be obtained in the following order: } \\
\text { (a) Weighted average emission factors (in } \mathrm{tCO}_{2} / \mathrm{MWh} \text { ) for all } \\
\text { generators in the current power grid published by authoritative bodies. } \\
\text { (b) If the option (a) is not available, the mixed marginal factor }(\mathrm{CM}) \text { is } \\
\text { calculated by the operation marginal factor }(\mathrm{OM}) \text { and the construction } \\
\text { marginal factor }(\mathrm{BM}) \text { according to the procedure stipulated in the } \\
\text { "Power System Emission Factor Calculating Tool". The weights are } \\
50 \% \text { each. } \\
\text { (c) In the case of power supply from self-owned power plants, the } \\
\text { power emission factors should be calculated according to the latest } \\
\text { version of the "Baseline, Projects and/or Leakage Emission Calculating } \\
\text { Tool Caused by Power Consumption". If the self-owned power plant } \\
\text { generates electricity from renewable energy sources, the power } \\
\text { emission factor is } 0 \text {. }\end{array}$ \\
\hline$I R$ & $\begin{array}{l}\text { Technical improvement factor } \\
\text { of t-year baseline ship. }\end{array}$ & $\begin{array}{l}\text { The rate of technological progress is applied to each calendar year. The } \\
\text { default value is } 0.99 \text {. }\end{array}$ \\
\hline$E C_{P J, i, y}$ & $\begin{array}{l}\text { Power supply for type I project } \\
\text { ships in year } \mathrm{Y}(\mathrm{MWh}) \text {. }\end{array}$ & $\begin{array}{l}\text { The measurement is carried out through the power supply monitoring } \\
\text { system of the shore power system. }\end{array}$ \\
\hline
\end{tabular}

\section{Example analysis}

A shore power project in East China is taken as an example in this paper. According to the data provided by port company, all ships use fuel as power during berthing before the project, which meets the requirement that " It is required that the power difference of fuel engine (including main engine and auxiliary engine) should be within $\pm 20 \%$ respectively". This project has additionality.

\subsection{Project Activity Descriptions}

The project achieves emission reduction by building shore power system and replacing fuel with electricity. Project emissions refer to the carbon dioxide emissions indirectly generated by ship power consumption. The annual electricity consumption of shore power is 13964 MWh. The monitored indicators are shown in Table 2.

Table 2. Monitored indicators

\begin{tabular}{|l|l|l|l|}
\hline Indicator & Unit & $\begin{array}{l}\text { numerical } \\
\text { value }\end{array}$ & $\begin{array}{l}\text { Data } \\
\text { usage }\end{array}$ \\
\hline$N C V_{\text {fuel }, i, y}$ & $\mathrm{GJ} / \mathrm{t}$ & 42.652 & $\begin{array}{l}\text { Calculating } \\
\text { Baseline } \\
\text { Emissions }\end{array}$ \\
\hline$E F_{\mathrm{CO}_{2}, i, y}$ & $\mathrm{t} \mathrm{CO} / \mathrm{GJ}$ & $74.067^{*} 10^{-3}$ & $\begin{array}{l}\text { Calculating } \\
\text { Baseline } \\
\text { Emissions }\end{array}$ \\
\hline$I R$ & - & 0.99 & $\begin{array}{l}\text { Calculating } \\
\text { Baseline } \\
\text { Emissions }\end{array}$ \\
\hline$E F_{\text {elec, }, y, y}$ & $\mathrm{t}$ & 0.5422 & $\begin{array}{l}\text { Calculating } \\
\text { project } \\
\text { emissions }\end{array}$ \\
\hline$T D L_{, y}$ & $\mathrm{CO} / \mathrm{MWh}$ & 6 & $\begin{array}{l}\text { Calculating } \\
\text { project } \\
\text { emissions }\end{array}$ \\
\hline
\end{tabular}

\begin{tabular}{|l|l|l|l|}
\hline$E C_{P J, i, y}$ & MWh & 13964 & $\begin{array}{l}\text { Calculating } \\
\text { project } \\
\text { emissions }\end{array}$ \\
\hline
\end{tabular}

\subsection{Pre-calculation of emission reduction}

(1)Baseline calculation

The fuel consumption of marine auxiliary power generation is $245 \mathrm{~g} / \mathrm{kWh}$, and the energy consumption ratio per unit berth time is:

$$
f_{i, y}=\frac{S F C_{\text {fuel }, i, y}}{S F C_{\text {elec }, i, y}}=\frac{245 * 10^{-6}}{1 * 10^{-3}}=0.245
$$

When diesel oil is used as fuel, the net calorific value of fuel oil is: $42652 \mathrm{~J} / \mathrm{g}=42.652 \mathrm{GJ} / \mathrm{t}$.

The emission factor of fossil fuels is: $20.2 \mathrm{t}-$ $\mathrm{C} / \mathrm{TJ} * 44 / 12=74.067 \mathrm{t}-\mathrm{CO}_{2} / \mathrm{TJ}=74.067 * 10^{-3} \mathrm{t}-\mathrm{CO}_{2} / \mathrm{GJ}$.

Baseline emissions are calculated as follows.

$B E_{y}=\sum f_{i, y} \times E C_{P J, i, y} \times N C V_{\text {fuel }, i, y} \times E F_{C O_{2}, i, y} \times I R^{t}$

$=0.245 * 13964 \mathrm{MWh} * 42.652 \mathrm{GJ} / \mathrm{t} * 74.067 * 10^{-3} \mathrm{t}$ -

$\mathrm{CO}_{2} / \mathrm{GJ} * 0.99$

$=10699.79 \mathrm{t}-\mathrm{CO}_{2}$

(2) Project emissions

The project is located in eastern China. According to the "Baseline Emission Factor of China Regional Power Grid for 2017 Emission Reduction Project"[4], the power emission factor is $0.5422 \mathrm{t}-\mathrm{CO}_{2} / \mathrm{MWh}$ and the power loss factor is 0.06 .

Project emissions are calculated as follows.

$$
\begin{aligned}
& P E_{y}=\sum_{i} E F_{\text {elec }, i, y} \times E C_{P J, i, y} \times\left(1+T D L_{i, y}\right) \\
& =0.5422 * 13964 *(1+0.06) \\
& =8025.56 \mathrm{t}-\mathrm{CO}_{2} \\
& (3) \text { Emission reduction } \\
& E R_{y}=B E_{y}-P E_{y} \\
& =10699.79-8025.56 \\
& =2674.23 \mathrm{t}-\mathrm{CO}_{2}
\end{aligned}
$$


According to the above calculation, the first year emission reduction of this project is 2674.23 tons of equivalent carbon dioxide.

\section{Conclusions}

The burning of fossil fuels is an important source of greenhouse gas emissions from port ships. Through the implementation of shore power system, it is possible to replace fuel consumption with electricity and significantly reduce greenhouse gas emissions during berthing. This paper studied and analyzed the existing greenhouse gas emission reduction methodologies, and defined the requirements of baseline determination, additionality demonstration, emission reduction calculation and monitoring plan formulation for portbased power supply projects. It provided a basis for quantitative calculation for shore power system to participate in carbon emissions trading. The research results are helpful to promote the application of shore power.

\section{Acknowledgement}

Fund Project, National Key R\&D Program of China 2016YFE02044800, Central-level nonprofit scientific research institutes basic research project special funds TKS170207, Tianjin transportation science and technology development plan project 3117044 . Tianjin Transportation Science and Technology Development Plan Project 2017C-04 ; Tianjin Transportation Science and Technology Development Plan Project 2017C-05 .

\section{References}

1. Interim Measures for the Management of Voluntary Greenhouse Gas Emission Reduction Transactions. $\mathrm{EB} / \mathrm{OL}$

http://qhs.ndrc.gov.cn/zcfg/201206/t20120621_4871 33.html, 2012-06-21.

2. Guidelines for Approval and Certification of Voluntary Greenhouse Gas Emission Reduction Projects.EB/OL. http://www.cerx.cn/CCER/345.htm, 2015-04-17.

3. National Voluntary Greenhouse Gas Emission Reduction Methodology Record List. EB/OL. http:/www.tanpaifang.com/fangfaxue/

4. Baseline Emission Factor of China Regional Power Grid for 2017 Emission Reduction Project. EB/OL. http://qhs.mee.gov.cn/kzwsqtpf/201812/P02018122 0579925103092.pdf, 2018-12-20. 